the USDA, which has focused more on development issues than the other agencies, is involved in policy formulation is a plus for the industry. The question is, how explicitly will the policy look to the biotechnology industry for safer alternatives to chemical pesticides?

Environmental groups-the World Wildlife Fund (Washington, DC), the Natural Resources Defense Council (New York), and the Environmental Working Group (Washington, DC)-actively lobbying the interagency committee have pushed for explicit "sunset-sunrise" provisions under which the phase out of high-risk pesticides would "trigger" research and development of safer alternatives, which would not exclude biotechnology but would not embrace it either. That is all well and good. But biotech executiveswho by now have a pretty good idea, as do the big agricultural-chemical companies, which insecticides, herbicides, and fungicides will have to be replaced in the next five years-would like a more explicit acknowledgment of the industry's potential role as a supplier of safe pesticides, specifically in the form of streamlined regulatory mechanisms for approval of new biotechnology products by the EPA.

The record so far suggests that Clinton's domestic policy advisers and the EPA leadership, while aware of the contribution biologicals can play in the development of alternatives to high-risk chemical pesticides, are deeply squeamish when it comes to biotechnology. In other words, those responsible for Clinton environmental policy still draw a sharp distinction, as did their predecessors in the Bush administration, between naturally occurring biological products and genetically engineered or manipulated ones, mostly for political reasons that have more to do more with perceived public acceptance than accepted science. The FDA and the USDA, however, may be more inclined to accept genetic engineering as an inevitable fact of agricultural biotechnology.

There is potential here for a judicious and innovative policy that not only reduces the risks of chemical pesticides, but also puts down markers for developing commercially viable, environmentally sound prod- ucts for the future. The interagency policy group is a positive sign that the Clinton administration is serious about marrying economic development and environmental protection in its new pesticide policy. Sound, tough regulatory policies necessary for public acceptance of biotechnology are largely in place. Without a full acknowledgment of the role biotech can play, however, chances are the outcome will be better environmental protection, but no signficant economic gains, or worse, economic losses. That is not good enough any more. Indeed, it is tantamount to backsliding for an administration that pours forth such enlightened economic and environmental rhetoric.

What is missing is leadership. As one biotech official muses, "You wonder when rhetoric will be put into action." The new pesticide policy is shaping up as the acid test for the Clinton administration on biotechnology. One way or another, the White House finally will have to reveal whether it is prepared to support the needs of this industry or whether it will let it twist in the wind of public opinion.

\title{
Designing and managing strategic alliances
}

Fully 51

percent of biotech firms

rely on

personal networking

by senior management

to select corporate

partners.
NEW YORK-Biotech companies usually take an informal approach to selecting strategic-alliance partners. Fully 51 percent of biotech firms rely on personal networking by senior management to select corporate partners. By contrast, only 18 percent of firms use formal internal-selection processes to identify partners. Another 18 percent of biotech firms are approached by corporate partners.

That's what KPMG Peat Marwick (Princeton, NJ) reports in a recent study entitled "Corporate Alliances: Strategies in Biotechnology," which aims to provide insight into the best ways to design and manage stategic alliances. Last year alone biotech companies and established pharmaceutical companies formed 215 strategic alliances. Among other study highlights:

- Money is the main driver of strategic alliances, as 31 percent of biotech companies cite access to capital as their primary reason for partnering. Another 18 percent of biotech companies cite reducing their product's time to market entry as a driving force, while 16 percent cite their partner's clinical skills and 15 percent cite validation of their technology.

- Established pharmaceutical firms supply the funds in 48 percent of alliances. Chemical companies bankroll 17 percent of alliances, while biotech companies bankroll 15 percent of alliances.

- Biotech companies most often receive milestone payments, getting them in 46 percent of alliances. In 45 percent of alliances, they get guaranteed research-and-development contract revenue. They receive both royalties and technology licensing fees in 39 percent of alliances.

- Biotech companies most often give up international marketing rights, relinquishing them in 53 percent of alliances. In 47 percent of alliances, they give up exclusive technology rights in a specific market. They relinquish U.S. market- ing rights in 38 percent of alliances and international manufacturing rights in 31 percent of alliances.

- Corporate-partner equity investments in biotech companies usually amount to 10 percent, or less, of a biotech company's stock. "Overall, large partners are not motivated by equity investment for profit. Instead, they will leverage this component to demonstrate a long-term commitment," the study states.

- With regard to technology licensing fees, 51 percent of biotech companies receive fees of less than $\$ 1$ million. Only 14 percent of biotech companies receive licensing fees of over \$5 million.

- Biotech firms typically receive royalties totaling 8 percent of product sales.

- Over half of strategic alliances are based on technology that is in its infancy, with 30 percent focusing on concept-stage technology and 22 percent targeting feasibility-stage technology.

-B.J. Spalding 